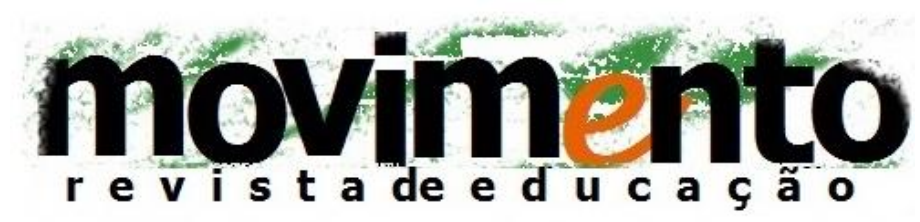

faculdade de educação - programa de pós-graduação em educação

universidade federal fluminense

issn 2359-3296

ano 3 número 5 - 2016

\title{
PROJETOS EMPRESARIAIS PARA A EDUCAÇÃO \\ O IPES e os CONEPEs na Ditadura Empresarial-militar brasileira
}

Renata Azevedo Campos ${ }^{1}$

\section{RESUMO}

Este artigo objetiva analisar as disputas, entre as frações empresariais, em torno dos rumos da reforma educacional da ditadura empresarial-militar brasileira. A principal questão colocada são os conflitos entre os empresários de ensino e o empresariado industrial, cujos interesses educacionais são, senão conflitantes, ao menos heterogêneos. Nessa perspectiva, o projeto educacional do Instituto de Pesquisa e Estudos Sociais será confrontado com as proposições dos empresários de ensino, participantes dos Congressos Nacionais dos Estabelecimentos Particulares de Ensino.

Palavras-chave: Projetos educacionais; IPES; CONEPEs.

\section{ABSTRACT}

This article aims to analyze the disputes between the corporate fractions around the course of the educational reform of the Brazilian corporate-military dictatorship. The main question is the conflict between educational entrepreneurs and industrial entrepreneurs, whose educational interests are, if not conflicting, at least heterogeneous. In this perspective, the educational project of the Instituto de Pesquisa e Estudos Sociais will be faced with the propositions of the educational entrepreneurs, participants of the Congressos Nacionais dos Estabelecimentos Particulares de Ensino.

Keywords: Educational projects; IPES; CONEPEs.

\footnotetext{
${ }^{1}$ Mestre em Educação pela UFF. E-mail: renataazevedort@gmail.com
} 


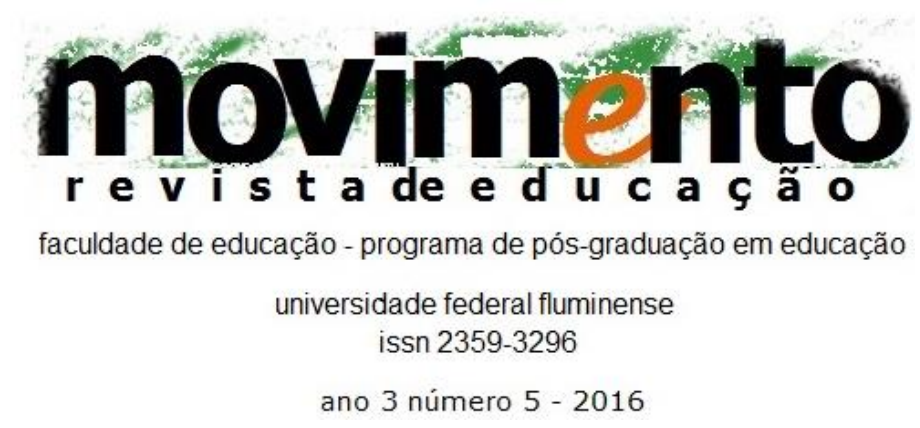

\section{Introdução}

O golpe empresarial-militar de 1964, protagonizado por civis e militares, foi uma solução encontrada pela burguesia multinacional e associada ${ }^{2}$ para ultrapassar as barreiras que se encontravam tanto entre outras frações dominantes quanto entre os trabalhadores. O seu projeto de desenvolvimento capitalista, marcado pelo controle oligopolista e pela abertura ao capital estrangeiro, não logrou a hegemonia com o conjunto da sociedade e precisou lançar mão de outros meios para a sua realização. $O$ golpe foi a face coercitiva da implementação desse projeto de sociedade para o qual o consenso fora, somente em parte, obtido. (DREIFUSS, 1981)

Após a retirada de Jango da presidência, a hora era de arrumar a casa; organizar e ocupar os aparelhos de Estado, assim como acomodar o aparato legislativo ao modelo de desenvolvimento em consolidação. A educação também fazia parte do projeto de sociedade, tendo em vista a formação dos quadros necessários e a contenção dos conflitos sociais.

A década de 1960 foi um marco do acirramento das lutas de classe em torno da educação; por um lado, os movimentos sociais conquistaram maior força e amplitude e, por outro, o crescimento urbano e industrial atrelou, mais diretamente, as possibilidades de desenvolvimento à extensão da formação escolar. Até esse momento, a política educacional encontrava-se defasada em relação à industrialização, mas possuía relativa coerência com um sistema econômico cuja produção agrária era ainda predominante e a industrialização

\footnotetext{
${ }^{2}$ A inserção do bloco multinacional, no Brasil, fez com que parte do capital brasileiro a ele tivesse que se associar para que pudesse coexistir nesse novo cenário de oligopólios.
} 


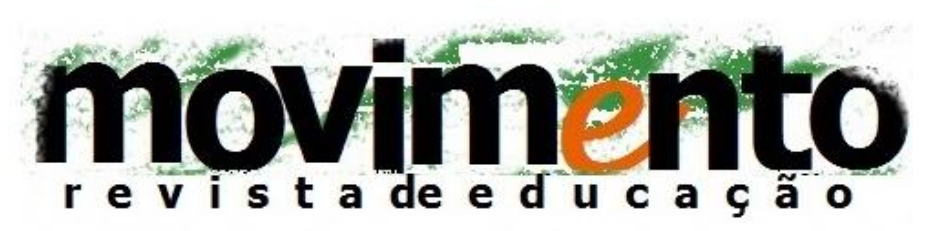

faculdade de educação - programa de pós-graduação em educação

universidade federal fluminense issn 2359-3296

ano 3 número 5 - 2016

ainda muito limitada. É com o novo modelo de desenvolvimento, gestado na década de 1950 e consolidado a partir do golpe de 1964, que essa defasagem se mostrará insustentável, tanto em função das novas atividades industriais, quanto da pressão social sobre a educação decorrente do crescimento urbano (FREITAG, 1986).

As reformas da ditadura empresarial-militar brasileira tiveram como principais consequências, para a educação, o recrudescimento de sua mercantilização e a inflexão tecnicista dos currículos (SAVIANI, 2008). Ainda que as duas consequências representem formas de subsunção da educação aos ditames do capital, elas parecem ter, em sua origem, interesses de frações de classe distintas.

Com efeito, vemos as demandas do empresariado como um todo serem contempladas no período, mas não podemos negligenciar as diferenças que envolvem essas mesmas demandas empresariais. A burguesia não se constitui como um bloco monolítico e isso também se aplica às questões relativas à educação. Nesse sentido, podemos observar distintas demandas educacionais relacionadas às diferentes frações empresariais. Para o capital comercial, por um lado, ela aparece como mercadoria-fim a partir da venda de serviços educacionais - educação-mercadoria. Por outro, aparece como um insumo necessário à produção de outra mercadoria, força de trabalho, para o capital produtivo - mercadoria-educação. A Mercadoria-educação requer, portanto, garantias mínimas de qualidade educacional na perspectiva de formação para o trabalho, contrariamente à educação-mercadoria que prevê maiores demandas e menores custos (RODRIGUES, 2007). 


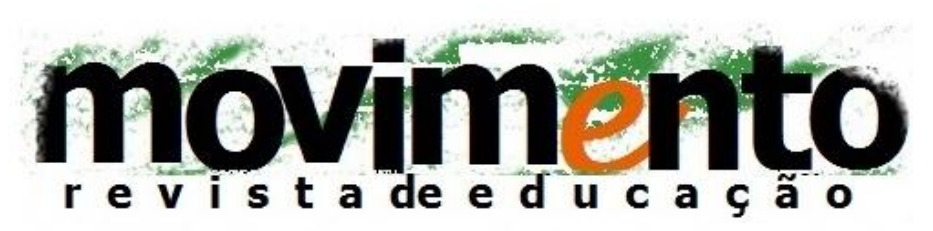

faculdade de educação - programa de pós-graduação em educação

universidade federal fluminense issn 2359-3296

ano 3 número 5 - 2016

$\mathrm{Na}$ perspectiva de analisar as heterogeneidades de interesses, e possíveis conflitos, entre essas duas frações burguesas, nos debruçaremos sobre duas organizações que, durante a ditadura empresarial-militar brasileiras disputaram e incidiram sobre os rumos das políticas públicas educacionais; o Instituto de Pesquisa e Estudos Sociais/IPES e os Congressos Nacionais dos Estabelecimentos Particulares de Ensino/CONEPEs.

Essa escolha do IPES se justifica pela sua centralidade na articulação do empresariado brasileiro, sob a direção das frações multinacionais e associadas. E também pelo fato do instituto ter sido a principal agência articuladora do Golpe de 1964, a partir do qual inseriu diversos de seus membros em postos estratégicos da administração pública. Da mesma forma, em meio aos vários sindicatos e associações de escolas particulares, os Congressos Nacionais dos Estabelecimentos Particulares de Ensino/CONEPEs, pareceram ser as fontes mais convenientes por reunir, em um mesmo espaço, diversos dirigentes e suas organizações (OLIVEIRA, 2002).

Em síntese, podemos dizer que tanto o IPES quanto os CONEPEs expressam o intuito das frações dominantes de coesionarem as suas demandas para apresentá-las de forma mais homogênea e, assim, garantir maior poder de pressão frente às reformas educacionais. $O$ Instituto de Pesquisa e Estudos Sociais/IPES e os Congressos Nacionais dos Estabelecimentos Particulares de Ensino/CONEPEs se mostraram como os representantes a partir dos quais poderíamos analisar as divergências entre as frações empresariais em questão. O IPES por ser a principal organização articuladora das frações mais dinâmicas do capitalismo brasileiro e os CONEPEs por serem capazes de reunir os mais diversos sindicatos e organizações das escolas particulares. 


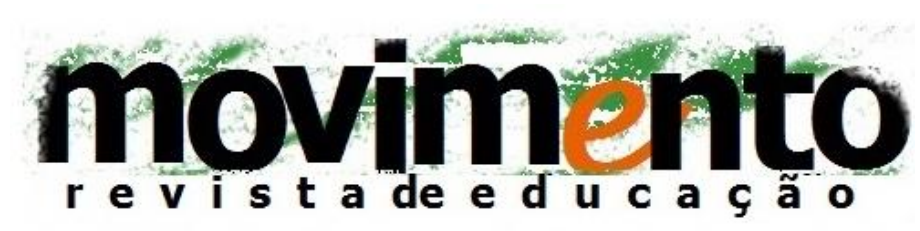

faculdade de educação - programa de pós-graduação em educação

universidade federal fluminense

issn 2359-3296

ano 3 número 5 - 2016

Tendo em vista a condução dessa análise, o artigo de dividirá em duas partes, além da introdução e da conclusão, sendo a primeira referente ao IPES e a segunda aos CONEPEs. No intervalo de 1964-1971 - período que aqui nos interessa em função de sua centralidade na formulação das políticas educacionais da ditadura - foram realizados, por essas instituições, alguns encontros $^{3}$ e é a partir deles que tentaremos esboçar algumas conclusões ${ }^{4}$.

\section{O Instituto de Pesquisa e Estudos Sociais}

Em fins da década de 1950 e início de 1960, as frações mais dinâmicas do capital atuante no Brasil não possuíam líderes reconhecidos e organizados, mas tão somente algumas associações de cunho mais setorial. Foi à luz dessa deficiência que alguns empresários e executivos do Rio de Janeiro e de São Paulo começaram a se reunir, ainda no governo de Jânio Quadros, formando então o núcleo dirigente do que viria a ser o IPES. A ativação formal do grupo, no entanto, só aconteceria em fins de 1961, quando a renúncia de Jânio colocara na presidência um político ligado aos sindicatos, João Goulart (DREIFUSS, 1981; SOUZA, 1981).

Oficializado em 29 de novembro de 1961, o lançamento do IPES foi favoravelmente recebido por diversos setores da imprensa, como Jornal do Brasil e O Globo, e também por alguns membros da Igreja Católica. A orientação

\footnotetext{
3 Pelo IPES, foram organizados um simpósio, em 1964, e um fórum, em 1968 (IPES, 1964a; IPES, 1964b; IPES, 1969). E, quanto aos CONEPEs, foram realizados cinco congressos, nos anos 1964, 1966, 1967, 1969 e 1971 (CONEPE, 1964; CONEPE, 1966; CONEPE, 1967; CONEPE, 1969; CONEPE, 1971). .

${ }^{4} \mathrm{O}$ presente trabalho tem por base a pesquisa realizada para a dissertação de mestrado: CAMPOS, Renata A. O IPES E OS CONEPEs: Conflitos e Consensos em torno dos rumos da política educacional da ditadura empresarial-militar brasileira. 2016. 202f. Dissertação (Mestrado em Educação) - UFF, Niterói.
} 


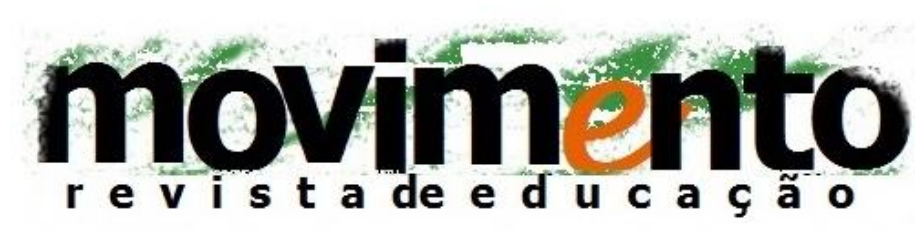

faculdade de educação - programa de pós-graduação em educação

universidade federal fluminense

issn 2359-3296

ano 3 número 5 - 2016

anticomunista e a sua motivação por uma reformulação do Estado contemplava não só os interesses da burguesia, mas também de amplas parcelas da sociedade cujo conservadorismo se amedrontava da proximidade que Jango tinha com o movimento sindical.

O IPES pode ser considerado, no sentido gramsciano, um partido político da burguesia, no qual uma parcela dessa classe possuía a capacidade de organizar os seus interesses com o objetivo de difundi-los e torná-los de toda a sociedade. (GRAMSCI, 2014) Essa perspectiva de construção da hegemonia se dava não somente em relação aos trabalhadores, mas, principalmente, em relação à própria classe burguesa. O núcleo fundador do instituto preocupava-se em conscientizar, sob sua direção, o empresariado do seu papel na sociedade, fazendo-os perceber que suas motivações não poderiam se restringir aos imediatos interesses corporativos.

Essa articulação da burguesia em torno de seus interesses, comuns e de longo prazo, não era construída, necessariamente, pelos próprios empresários, mas também pelos intelectuais a eles ligados, os chamados intelectuais orgânicos ${ }^{5}$. Como afirma Gramsci:

Cada grupo social, nascendo no terreno originário de uma função essencial no mundo da produção econômica, cria para si, ao mesmo tempo, de um modo orgânico, uma ou mais camadas de intelectuais que lhe dão homogeneidade e consciência de sua própria função, não apenas no campo econômico, mas também no social e no político: o empresário capitalista cria consigo o técnico da indústria, o cientista da economia política, o organizador de uma nova cultura, de um novo direito etc. (GRAMSCI, 1979, p. 3-4).

\footnotetext{
${ }^{5}$ Dentre esses intelectuais orgânicos, cabe pontuar os chamados tecno-empresários que se destacavam pela atuação em diretorias de empresas e pela ingerência no aparelho do Estado. O conceito tecno-empresários qualifica, em termos de ligação com frações de classe, os ditos tecnocratas que ocuparam postos no Estado na década de 1960, em especial, após o golpe.
} 


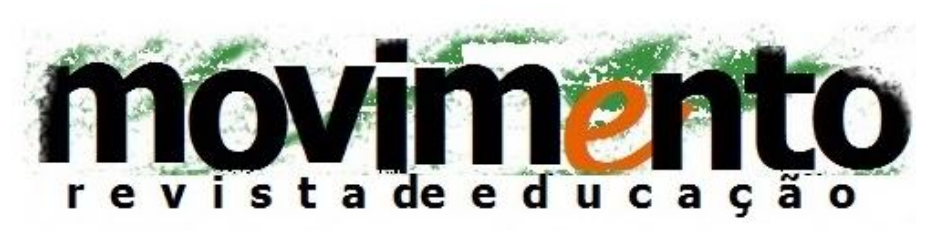

faculdade de educação - programa de pós-graduação em educação

universidade federal fluminense issn 2359-3296

ano 3 número 5 - 2016

Em função do prestígio conquistado, o IPES rapidamente se expandiria e se organizaria em outras cidades, como Porto Alegre, Santos, Belo Horizonte, Curitiba, Manaus e outros lugares menores. Não obstante, sua elite orgânica se centralizava no então estado-cidade da Guanabara e em São Paulo, onde eram compostas direções regionais formadas por um Conselho Orientador, um Comitê Diretor e um Centro Executivo, a partir das quais saíam os diretores nacionais. Os postos dessas esferas organizacionais eram, em sua maioria, ocupados por "proprietários, acionistas, presidentes e diretores dos interesses multinacionais e associados operando no Brasil" e também por "oficiais militares de prestígio" (DREIFUSS, 1981, p. 173). Se, por um lado, a ampla distribuição dos postos significava uma preocupação com a concentração indevida de poder, por outro, a ocupação de postos de maior destaque demonstrava a hegemonia dos grandes empresários no interior do IPES.

Tendo como objetivos a contenção da suposta ameaça comunista, materializada no governo de João Goulart, e a objetivação dos interesses monopolistas na ossatura do Estado, a elite orgânica organizada no IPES necessitava não somente coesionar o empresariado, mas também conquistar a legitimidade para sua ação junto à sociedade como um todo, ou pelo menos parte dela. Contava, além dos empresários, com a presença de professores universitários, técnicos e especialistas que agiam conforme a sua tática de contrapropaganda aos projetos da esquerda e também de elaboração de propostas concretas. Dessa forma, suas atividades tinham dupla dimensão, uma pública e outra clandestina, sendo essa última voltada, principalmente, para a corrosão do governo Jango (SOUZA, 1981; NETTO, 2014; DREIFUSS, 1981). 


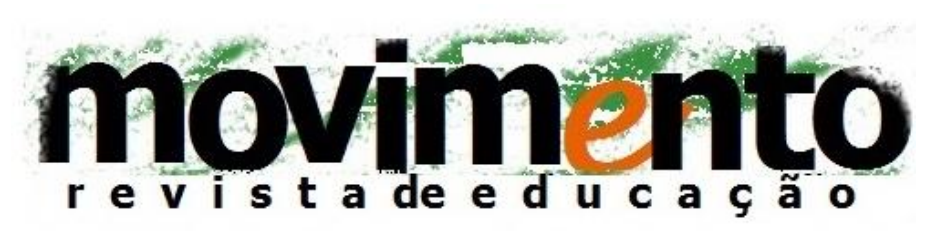

faculdade de educação - programa de pós-graduação em educação

universidade federal fluminense issn 2359-3296

ano 3 número 5 - 2016

Paralelo a essa articulação militar, o IPES mantinha uma atuação pública que se direcionava para o conjunto da burguesia e para a sociedade como um todo. Internamente ao bloco burguês, o objetivo era a conscientização empresarial de seu papel no encaminhamento dos problemas que afligiam o Brasil. Nesse sentido, eram organizados seminários, encontros, publicações e reuniões mais restritas, como forma de coesionar o empresariado sob a hegemonia da fração multinacional e associada. Nesse intuito, foram realizados dois encontros, já posteriores ao golpe, para tratar do problema educacional e das reformas que se avizinhavam: o Simpósio para a Reforma da educação, de 1964, e o Seminário "A educação que nos convém", de 1968.

As iniciativas do IPES cumpriam, dessa forma, uma função educativa de difusão de uma visão de mundo e articulação para sua formalização enquanto política de Estado. Enquanto alguns materiais, como os filmes, visavam os setores subalternizados para legitimação de seu projeto de sociedade, os estudos temáticos e as conferências se destinavam ao empresariado e aos sujeitos envolvidos tendo em vista o protagonismo de suas ideias nos rumos das reformas que estavam por vir.

Ainda que os encontros tenham delineado o projeto educacional das frações mais dinâmicas do capitalismo brasileiro, eles também foram a expressão da luta de classes e da forma como essas frações procuravam lidar com as tensões entre capital e trabalho. Combinando concessão e silenciamento, o IPES buscou elaborar um projeto de educação que, articulado a um orgânico projeto de classe, fosse capaz de dialogar com amplos setores da sociedade.

A tarefa de adequar a política educacional à dinâmica de crescimento industrial, que envolve a formação e a conformação da classe trabalhadora, foi capitaneada 


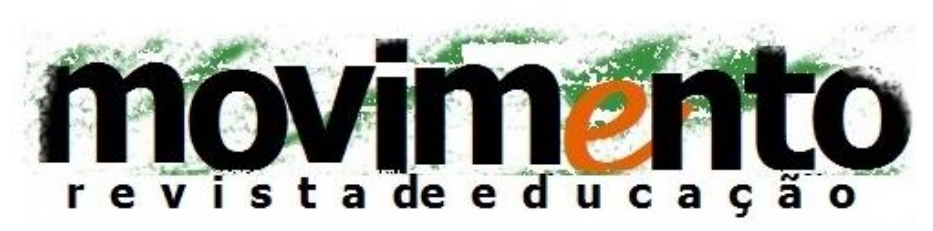

faculdade de educação - programa de pós-graduação em educação

universidade federal fluminense issn 2359-3296

ano 3 número 5 - 2016

pelo IPES em conformidade com o seu projeto de classe. Nesse aspecto, duas questões se destacam: 1) o projeto educacional do IPES era parte de um projeto geral de sociedade; 2) como articulador de um projeto de sociedade, o IPES precisava ser permeável às demandas externas, e até opostas, aos seus interesses. Com isso, destacamos o papel do Instituto não como um mero aparelho defensor de interesses corporativos, mas como um partido político da burguesia, cujo projeto de sociedade colocava em destaque o papel da educação. Atuando como um partido, com a perspectiva de coesionar e difundir os interesses empresariais de longo prazo, o IPES necessitava dialogar com as diversas frações da classe dominante e também com algumas demandas da classe dominada, ainda que sob a hegemonia dos interesses multinacionais e associados. Interesses esses que se articulavam, de forma subordinada, à dinâmica global de reprodução do capital, tendo como foco decisório os países centrais - determinantes específicos que configuram o capitalismo em sua modalidade dependente. (FERNANDES, 2005)

Para melhor compreender a relação entre esse modelo de desenvolvimento associado-dependente e as suas demandas para educação, nos debruçaremos sobre os encontros realizados, pelo IPES, para tratar da temática educacional.

\section{O simpósio de 1964}

O primeiro encontro, organizado pelo IPES, que tratou exclusivamente da questão educacional foi realizado em fins de 1964 e suas atividades ainda perduraram nos primeiros meses de 1965. As primeiras ideias para o encontro, assim como o início de sua elaboração, datam de agosto de 1964; posteriores, 


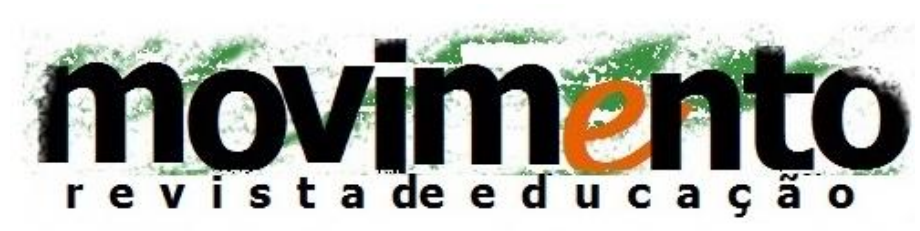

faculdade de educação - programa de pós-graduação em educação

universidade federal fluminense

issn 2359-3296

ano 3 número 5 - 2016

portanto, ao golpe de Estado a partir do qual muitos dos intelectuais orgânicos do Instituto se fizeram presentes nos aparelhos estatais. Para uma melhor compreensão das proposições feitas nesse momento, é necessário que elas sejam inseridas nesse contexto do pós-golpe, quando a abertura aos interesses do capital monopolista e a repressão social geraram expectativas positivas quanto à concretização dos interesses multinacionais e associados.

Já em seus meses iniciais, a ditadura foi marcada, por um lado, pela repressão à oposição, tendo como teoria legitimadora a Doutrina de Segurança Nacional ${ }^{6}$ e, por outro, pela defesa do capital monopolista, principalmente dos setores internacionalizados, em detrimento das condições de vida do trabalhador. A bem sucedida associação com militares trouxe uma confiança para as classes dominantes brasileiras quanto à estabilidade política necessária para a vitória de seu projeto econômico. O Simpósio sobre a Reforma da educação é expressão desse otimismo, onde são delineadas as linhas gerais de seu projeto educacional.

Observamos que a proximidade com o golpe conferiu ao simpósio uma limpidez na definição de suas propostas e uma menor necessidade de abrir concessões, principalmente aos estudantes, por duas razões principais. Em primeiro lugar, porque a composição do aparato estatal tendo a frente um militar ligado à Escola Superior de Guerra, como Castelo Branco ${ }^{7}$, garantiu ao IPES a presença em importantes cargos da administração pública. Em segundo, porque, já em seus primeiros dias, a ditadura colocou em funcionamento o seu aparato repressivo,

\footnotetext{
${ }^{6}$ A Doutrina de Segurança Nacional foi formulada no interior da Escola Superior de Guerra e, articulando o desenvolvimento econômico com a segurança interna, tinha como eixo norteador a identificação e eliminação dos inimigos internos - os comunistas (NETTO, 2014).

7 No interior das forças armadas existiam frentes em disputa, em meio a qual o IPES encontravase associado aos militares formados na Escola Superior de Guerra, conhecidos como Grupo Sorbonne.
} 


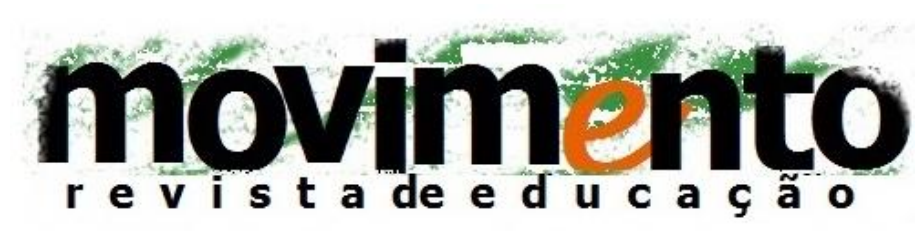

faculdade de educação - programa de pós-graduação em educação

universidade federal fluminense

issn 2359-3296

ano 3 número 5 - 2016

a partir do qual pressionava tanto o movimento de trabalhadores quanto o de estudantes. O aparelhamento do Estado combinado à repressão aos movimentos sociais parece ter dado ao Instituto a confiança para lançar o seu ideal de educação de modo a dirigir a reforma esperada. Sobre o simpósio, saiu no boletim do IPES, de novembro de 1964:

Essa iniciativa, que representa um esforço sério visando à definição das linhas mestras de uma política educacional capaz de abrir para o nosso país possibilidades de acesso à categoria de potência internacional, encontrou franca acolhida por parte de eminentes personalidades, cuja elaboração solicitamos em nome do Brasil, e que se vem notabilizando pelo saber e pela experiência nos mais diversos setores de atividades, públicos e privados (IPES, 1964c, p. 277).

É interessante notar como a educação, que deveria contribuir na construção do consenso, precisava antes ser higienizada através da coerção; demonstrando que a eficiência de um aparelho de consenso depende do aparato coercitivo que o cerca. Passadas as instituições educativas, e seus agentes combativos, pelo pente repressivo da ditadura ${ }^{8}$, o IPES parecia crer que a instabilidade política tinha seus dias contados. É à luz desse contexto, de satisfação com os rumos do país e confiança de sua ingerência na condução do processo, que analisamos o Simpósio sobre a Reforma da Educação.

O Simpósio foi, portanto, chamado para organizar as diretrizes básicas da reforma educacional requerida pelos empresários organizados no IPES, tendo como perspectiva o desafio que então se colocava - a superação do

\footnotetext{
${ }^{8}$ Não queremos dizer que a resistência tenha findado, mas que as classes dominantes tinham esperança em relação ao sucesso de sua campanha repressiva.
} 


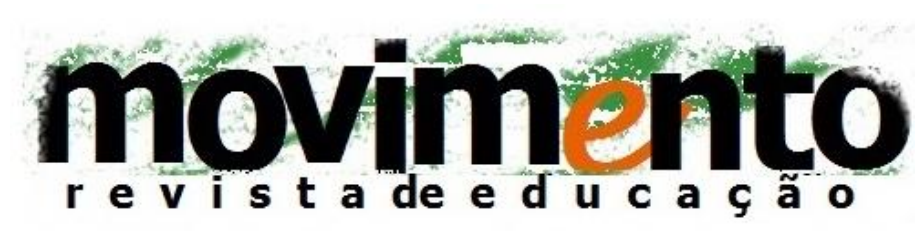

faculdade de educação - programa de pós-graduação em educação

universidade federal fluminense

issn 2359-3296

ano 3 número 5 - 2016

subdesenvolvimento 9 . Superação essa que tinha na educação uma mediação fundamental, visto que o subdesenvolvimento materializava-se em:

[...] seu espírito incultivado: no desconhecimento das mais adequadas técnicas de trabalho, quer no campo, quer na cidade; na insuficiente capacidade de organização e de direção; no despreparo das elites para responder aos desafios dos novos tempos; na irresponsabilidade que campeia livre em todos os quadrantes do país (IPES, 1964c, p. 278).

Para embasar o debate entre os convidados, foram distribuídos dois textos: um deles foi intitulado "Delineamento Geral de um Plano de Educação para a Democracia no Brasil", de autoria de José Roberto Moreira e outro "Documento Básico", sem autoria definida. Peri Pôrto foi o seu principal organizador, sendo um integrante do IPES com grande incidência na administração pública e que veio a colaborar, inclusive, na elaboração do Plano de Ação Econômica do Governo/PAEG, de 1964, onde a educação aparece pela primeira vez como capital humano. Figuras de destaque na construção das políticas educacionais foram convidadas para o simpósio; dentre especialistas, economistas e empresários, foi também convidado Raimundo Muniz de Aragão, que seria um dos ministros de educação, no ano de 1966.

$\mathrm{Na}$ realidade, a própria organização do encontro como um simpósio - cujo debate se fez sobre textos anteriormente distribuídos e do qual não resultou nenhum documento conclusivo - representa que a ideia era difundir, e consensuar, uma perspectiva de reforma educacional que já vinha se delineando anteriormente. Para tanto, a escolha dos participantes era de suma importância.

\footnotetext{
${ }^{9} \mathrm{~A}$ caracterização do problema como de subdesenvolvimento já é sintomática da tentativa de obscurecer as relações de dependência, a partir de uma compreensão para a superação de estágios de desenvolvimento e não de relações sociais que configuram relações de poder.
} 


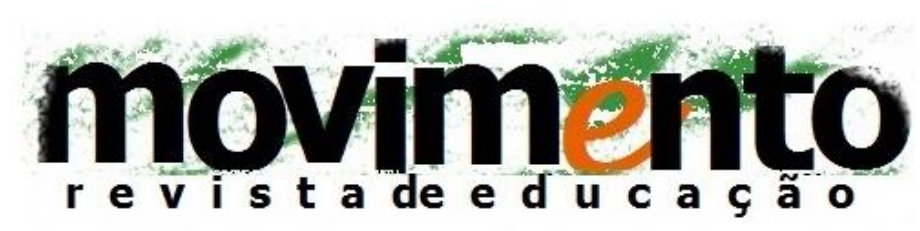

faculdade de educação - programa de pós-graduação em educação

universidade federal fluminense

issn 2359-3296

ano 3 número 5 - 2016

Não possuímos documentação suficiente para saber quem, de fato, participou, mas tão somente daqueles que para o Simpósio foram convidados. As variadas vinculações dessas figuras são reveladoras do tipo de articulação que o IPES fazia, de modo a construir o consenso com diversos setores da sociedade e garantir sua direção no conjunto de reformas que então se avizinhava. Essas articulações agiam no sentido de fazer ecoar as propostas do Instituto, mesmo em espaços onde ele não se encontrava representado. ${ }^{10}$

Na matéria convocatória para o simpósio, que integrava o boletim de novembro de 1964 do IPES, as linhas gerais do que seria defendido já se delineavam. O ponto principal era que desenvolvimento almejado chamava por uma reformulação qualitativa e quantitativa da educação, com ênfase na transformação do ensino secundário de modo a preparar a força de trabalho para a indústria e o comércio, além da necessidade de contemplar o desenvolvimento científico e tecnológico.

Quanto aos textos distribuídos, podemos observar que os dois possuíam uma avaliação e uma linha de ação semelhantes, ainda que sob formas diferenciadas de colocar os problemas. As diretrizes centrais eram dadas pelos estudos acerca do capital humano ${ }^{11}$ e da centralidade do avanço técnico na quantidade de desenvolvimento, assim como do retorno individual e nacional com base no investimento em educação. Nesse sentido, a educação era colocada no interior

\footnotetext{
10 Podemos citar como exemplo, a presença, no coquetel de abertura, de três importantes figuras: Suzana Gonçalves, presidente da CAPES na época; Gilberto Huber, empresário e portavoz de seus interesses; Mário Henrique Simonsen, economista que viria a ser ministro do planejamento.

${ }^{11}$ A Teoria do Capital Humano, difundida nos EUA em meados da década de 1950, sustenta, em linhas gerais, a educação como um fator de desenvolvimento e que, portanto, deve estar a serviço das necessidades do mercado.
} 


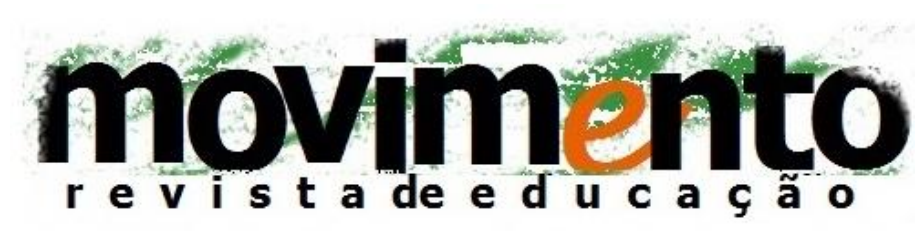

faculdade de educação - programa de pós-graduação em educação

universidade federal fluminense

issn 2359-3296

ano 3 número 5 - 2016

da ciência econômica como um bem de consumo e como um bem imaterial de produção. Para o ensino superior, era defendida a ênfase na ciência, na técnica e na profissionalização, concomitante ao ensino erudito. E para o grau médio, pautava-se um maior direcionamento em relação ao mercado de trabalho, tendo em vista o despreparo dos jovens egressos desse nível. Seguindo uma argumentação semelhante aos princípios da Teoria do Capital Humanos (SCHULTZ; 1973), o "Documento Básico" colocou:

No que diz respeito à educação, sua relação de causa e efeito com o crescimento sócio-econômico manifestou-se historicamente em alguns casos específicos bastante conhecidos: o Japão, por exemplo, nação pobre em recursos naturais, desenvolveu-se mais cedo e mais rapidamente que os países seus vizinhos, dotados de maiores potencialidades materiais. Tal fato somente pode ser atribuído ao aperfeiçoamento de seus quadros de ensino (IPES, 1964a, p. 31-2).

Apesar de nenhum dos dois textos serem claros quanto à reprodução dos determinantes da condição de dependência, como foram algumas das conferências do Fórum "A educação que nos convém", sobre o qual trataremos mais adiante, eles trazem questões que desvelam sua avaliação do país e sua perspectiva de desenvolvimento. É o que nos sugere a inserção do problema educacional brasileiro no quadro do subdesenvolvimento, caracterizado a partir de diversos sintomas comparáveis entre os diversos países: renda per capita, desigualdade, saúde, alimentação, escolarização, urbanização etc. Dessa forma, a superação da condição de atraso, inerente à ideia de subdesenvolvimento, passaria pela valorização e adequação da educação às demandas do desenvolvimento econômico; desenvolvimento esse caracterizado pela importação de tecnologia e negligência em relação ao conhecimento científico autônomo. 


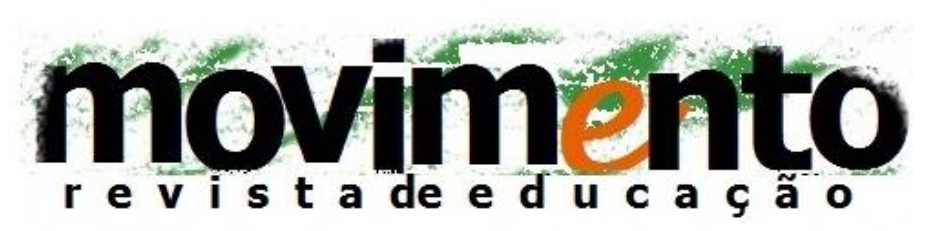

faculdade de educação - programa de pós-graduação em educação

universidade federal fluminense issn 2359-3296

ano 3 número 5 - 2016

Além das comentadas alterações propostas para a organização do ensino, a visão produtivista de educação também se manifestou com a proposição da participação empresarial nos conselhos universitários e a articulação dos ministérios de planejamento e educação. Combinado à ingerência dos empresários e de suas demandas econômicas nas questões educacionais, os textos fizeram propostas que reduziam a autonomia das instituições educativas e de seus profissionais. Dentre elas, podemos destacar o norteamento da educação a partir de dados estatísticos e a avaliação do corpo docente e do rendimento escolar através de inspeções e testes, a serem aplicados por órgãos de direção da educação. Quanto aos estudantes, além de terem suas reivindicações ridicularizadas, a representação em órgãos colegiados foi totalmente criticada.

De modo geral, podemos avaliar que essa combinação, de participação empresarial e silenciamento dos sujeitos combativos, foi a linha geral de atuação do IPES para garantir a subsunção da educação aos interesses do capital, mesmo nos anos seguintes.

\section{Fórum de 1968}

O Fórum "A Educação que nos convém" é analisado, por diversos pesquisadores ${ }^{12}$, como um símbolo não somente da articulação empresarial em torno da educação, mas também da própria política educacional que se seguiria. A relevância e a capacidade de ressonância desse encontro decorrem, em nossa análise, da tática adotada, a partir da qual foram reunidos diversos especialistas

${ }^{12}$ Destacamos aqui os trabalhos de Cunha (1988) e Saviani (2010). 


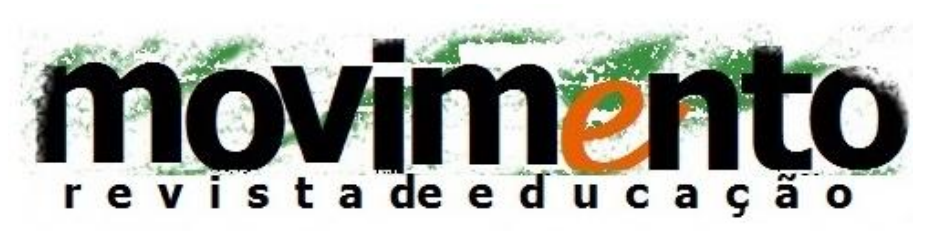

faculdade de educação - programa de pós-graduação em educação

universidade federal fluminense issn 2359-3296

ano 3 número 5 - 2016

com perspectivas diferentes, mas conciliáveis. Além de contemplar diversos setores que sobre a educação se debruçavam, o fórum buscou dar conta dos projetos alternativos, submetendo-os ao projeto hegemônico através do silenciamento de seus sujeitos. Essa mudança tática, em relação à unicidade de perspectiva do simpósio de 1964, se relaciona com a nova correlação de forças, em que as lutas do movimento estudantil se tornavam incontornáveis. Se, em 1964, havia uma expectativa com a capacidade de contenção dos conflitos através do aparato repressivo militar, a manutenção da resistência nos anos seguintes mostrou que a coerção não seria suficiente.

De modo geral, podemos dizer que a agitação estudantil se inseria em um quadro de inadequação entre o ensino superior, a estrutura produtiva e o grau de urbanização da sociedade. Num contexto em que a industrialização expandiu o mercado de trabalho para as profissões universitárias, o ensino superior precisava se compatibilizar tanto quantitativa quanto qualitativamente com as novas demandas do crescimento econômico e do avanço da urbanização. Ampliava o problema dos excedentes o fato de a conjuntura econômica pós-64 dificultar a ascensão das camadas médias via investimento e reprodução de capital, gerando uma maior demanda pelo ensino superior. Em meio ao conturbado contexto, a esquerda do movimento estudantil buscava canalizar a insatisfação dos estudantes (ROMANELLI, 1982).

Agravava, portanto, a situação das classes dominantes o fato de o movimento estudantil enfraquecer uma das bases de sustentação do regime, os setores médios da sociedade. Se, inicialmente, esses setores médios urbanos foram favorecidos pela ampliação do número de vagas no ensino superior, o modelo econômico os prejudicava, em médio prazo, ao favorecer as grandes empresas em detrimento das pequenas. Em consequência, a demanda por vagas no 


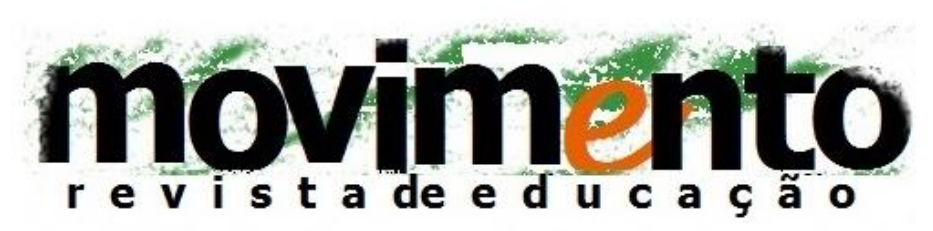

faculdade de educação - programa de pós-graduação em educação

universidade federal fluminense issn 2359-3296

ano 3 número 5 - 2016

ensino superior cresceu mais do que a sua disponibilidade, gerando a crise estudantil que teve seu ponto máximo em 1968.

Por essas razões, ainda que o Fórum tenha se realizado em um cenário de forte repressão aos movimentos sociais, a pressão dos estudantes não pode ser desconsiderada no entendimento de suas resoluções finais. As propostas do IPES, em termos educacionais, buscaram dar conta dos anseios dos jovens insatisfeitos e, ao mesmo tempo, silenciar aqueles que atuavam junto a entidades combativas como a UNE. O que se preconizava era a combinação de coerção e persuasão também com estudantes na criação desse novo ethos educativo, em conformidade com o espírito do capitalismo monopolista.

Realizado em outubro e início de novembro de 1968, o Fórum "A educação que nos convém" foi dividido em onze temas, para os quais havia um conferencista e um ou dois debatedores convidados; além desses, algumas pessoas da plateia também se inscreveram nos debates. Dentre esses sujeitos, havia membros internos e externos da Universidade, do IPES e do governo, sendo que nenhum era estudante ${ }^{13}$. Como destacamos, esse encontro é elucidativo da tática utilizada pelo IPES no sentido da conformação de interesses diversos, sob a direção de suas frações hegemônicas e em articulação com agentes da aparelhagem estatal.

As diversas conferências, e seus debates, tinham recortes diferentes e perspectivas heterogêneas, em conformidade com a posição social dos sujeitos e seus diferentes pontos de vista. No entanto, ainda que preocupado em trazer os diferentes setores que atuavam ou gravitavam em torno da política

\footnotetext{
${ }^{13}$ Há indícios de que o convite de estudantes foi objeto de polêmica entre os organizadores (SOUZA, 1981).
} 


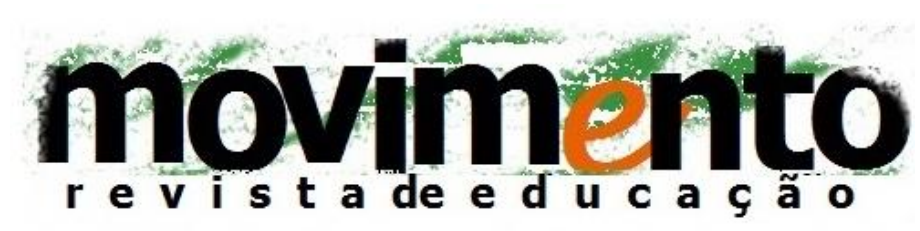

faculdade de educação - programa de pós-graduação em educação

universidade federal fluminense issn 2359-3296

ano 3 número 5 - 2016

educacional, o IPES se propunha a articulação de um determinado campo de interesses, compatível com a política econômica das frações multinacionais e associadas. Nesse sentido, as demandas do movimento estudantil, por exemplo, atravessam todo o fórum, mas de forma mediada pelas vozes de economistas, administradores educacionais, engenheiros etc., e nunca protagonizadas pelos próprios estudantes.

O reconhecimento da luta estudantil, concomitante a critica de suas táticas e ideais, foi uma unanimidade entre aqueles que comentaram o problema. O que se mostra latente é a compreensão, entre os conferencistas e debatedores, de que a crise estudantil era incontornável, mas que deveria ser pautada a partir de outros interesses, os seus. O conferencista Lucas Lopes, após valorizar a crítica a tudo feita pelos estudantes, conclama: "Vamos nós, que não estamos compromissados apenas com a destruição, tentar formular algo de construtivo" (IPES, 1969, p. 129).

Podemos perceber que as demandas do movimento estudantil e a preocupação com o mesmo aparecem, de modo mais assertivo, no simpósio de 1968; provavelmente, em função do acirramento dos conflitos. Nesse sentido, contribuem para a compreensão do projeto educacional do IPES e da tática utilizada a diferença do tom e das propostas em 1964 e 1968, em relação com a correlação de forças destacada.

Em primeiro lugar, podemos observar uma mudança no tratamento da questão estudantil. Em 1964, os estudantes e suas demandas eram menosprezados, o que fica evidente no texto de José Roberto Moreira (1964b): "não se cria menor pressão para que deixem de ser crianças mal educadas e ligeira ou escandalosamente irresponsáveis." Enquanto em 1968, o movimento estudantil 


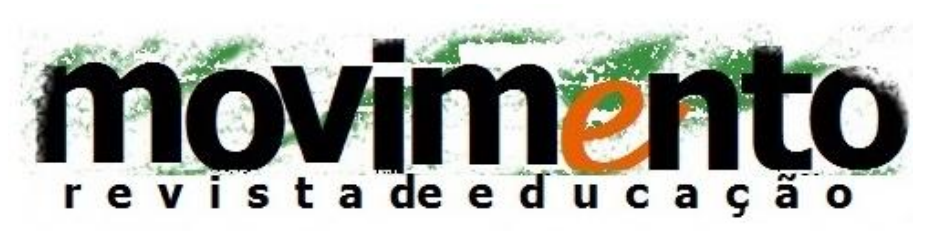

faculdade de educação - programa de pós-graduação em educação

universidade federal fluminense issn 2359-3296

ano 3 número 5 - 2016

é reconhecido e a revolta dos estudantes é legitimada. Como afirmou o Padre Fernando Bastos D’Ávila: "É assim oportuno buscar explicitar o problema dos objetivos e métodos da educação nacional, num momento em que as indagações radicais se tornaram inevitáveis" (IPES, 1969).

Uma segunda diferença aparece quanto à representação nos órgãos colegiados. Se, no simpósio de 1964, a representação era totalmente criticada, no fórum, ela é defendida ainda que de forma limitada. E, por fim, em 1968, a profissionalização do Ensino Médio é aventada como forma de conter a demanda pela universidade.

Observando a inevitabilidade de certos movimentos, essa era a tarefa que o IPES parecia se colocar, se antecipar às mudanças que estavam em curso, de modo a encaminhar o seu projeto e submeter aos seus interesses os outros projetos que não poderiam ser negligenciados. A reforma educacional era importante para as frações que se organizavam e dirigiam o IPES, na perspectiva de vinculação da educação com o mercado de trabalho, o que, ao mesmo tempo, também possuía um caráter persuasivo ao representar as demandas de ascensão social.

Na perspectiva de construção do consenso e direção da pauta educacional, não somente as demandas estudantis estiveram presentes no encontro realizado pelo IPES, mas também de outros agentes com os quais os empresários e seus intelectuais precisavam se articular, como professores e dirigentes educacionais. Nesse caso, contrariamente ao que acontecia com os estudantes, os sujeitos foram convidados a participar do evento, tendo em vista uma elaboração coletiva sobre os rumos da educação no Brasil. A representatividade e a trajetória de tais convidados demonstra que sua seleção se deu a partir de alguns critérios, como 


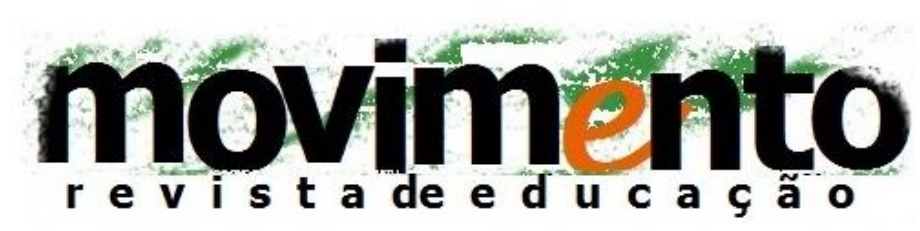

faculdade de educação - programa de pós-graduação em educação

universidade federal fluminense

issn 2359-3296

ano 3 número 5 - 2016

a coerência com o projeto educacional do IPES, o trânsito nas esferas decisórias da administração pública e a participação na execução das políticas educacionais.

Essa composição se inseria em um cenário específico da política educacional brasileira, em que a Lei da Reforma Universitária já estava em tramitação ${ }^{14}$ e a necessidade de reformar a LDB/61 começava a dar seus sinais ${ }^{15}$. Tendo em vista a concordância da lei em tramitação com o projeto educacional do IPES, podemos aferir que o Fórum de 1968 servia mais à legitimação de uma reforma já em curso e à adequação da nova legislação à realidade educacional. Isso porque, entre a lei e a prática, há um grande caminho no qual a capacidade de adaptação dos operadores da política é fundamental. Ao mesmo tempo, o Fórum iniciava uma formulação e articulação em torno da necessária reforma do então ensino primário e médio, adequando-a aos seus interesses.

A despeito das diferenças entre os dois encontros realizados pelo IPES, salta aos olhos a forma como a educação era chamada a resolver os problemas de uma forma específica de desenvolvimento capitalista dependente. Nesse sentido, além de seguir a mesma linha do simpósio anterior quanto ao vínculo entre educação e economia, a maioria das falas do fórum prioriza a formação da mão de obra qualificada em detrimento da produção de conhecimento científico e da autonomia universitária. Nessa perspectiva, a relação entre educação e

\footnotetext{
${ }^{14}$ O Fórum se iniciou em 10 de outubro de 1968 e finalizou seus trabalhos em 18 de novembro do mesmo ano. O relatório e os anteprojetos elaborados pelo Grupo de Trabalho da Reforma Universitária/GTRU foram entregues em 16 de agosto de 1968 e permaneceram até 2 de outubro com a assessoria presidencial, quando seguiu para o congresso. Voltou para o presidente em 2 de novembro e, após os vetos, foi sancionado em 28 de novembro (CUNHA, 1988). Mesmo antes do Grupo de Trabalho, alguns decretos já vinham reformulando o ensino superior de modo semelhante ao que viria a se oficializar com a Lei no 5.540/68.

15 Prevendo a insuficiência da reforma universitária para a contenção das tensões que pressionavam pela expansão do ensino superior, a profissionalização do ensino médio, já no relatório do GTRU, despontava como um meio de fazer desse um nível terminal.
} 


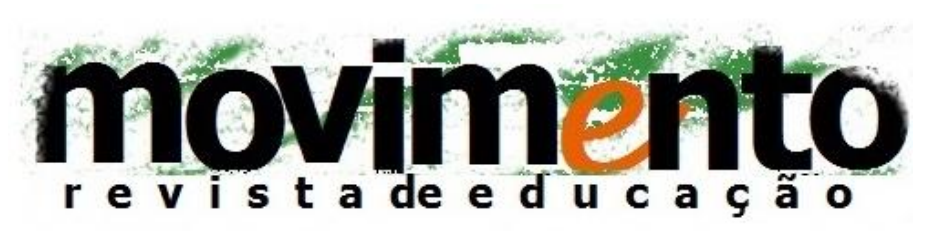

faculdade de educação - programa de pós-graduação em educação

universidade federal fluminense issn 2359-3296

ano 3 número 5 - 2016

desenvolvimento se traduzia em um projeto educacional que reproduzia o modelo de desenvolvimento econômico hegemônico. Assim, a quantidade de educação a ser oferecida deveria ser compatível com a quantidade de educação exigida pelos setores produtivos. Para que os interesses empresariais prevalecessem na condução do processo educacional, os dirigentes do IPES defendiam repetidas vezes a necessidade de incluir as empresas nos processos decisórios; nos conselhos e através de financiamentos e estágios.

A subsunção da educação às demandas do capital era o eixo de manutenção do projeto educacional do IPES que precisava, ao mesmo tempo, negociar com os setores em disputa como forma de reproduzir a sua estrutura de dominação. A defesa de seu projeto educacional se dava não somente pela fala dos membros do Instituto, mas também pela conformação de defesas externas.

O Fórum "A educação que nos convém" conquistou maior ressonância na sociedade em função de seu caráter público e da organicidade de suas ideias, sendo reconhecido, na época e posteriormente, como um dos norteadores da política pública educacional da ditadura, principalmente no que se refere à universidade. No entanto, como destacamos, ele parece ter tido como função principal, para além de uma elaboração original, a legitimação da reforma universitária que já estava em curso e, ao mesmo tempo, a preparação para a reforma do ensino de $1^{\circ}$ e $2^{\circ}$ graus, que ocorreria em 1971 . O ensino superior foi o protagonista nas temáticas, mas pouco espaço ainda havia para alterações no processo de reforma em fases finais de conclusão.

A linha geral da política educacional defendida pelo IPES já estava acertada desde o simpósio de 1964, mas algumas propostas e táticas se modificaram em função das transformações vividas pela sociedade ao longo desses anos. A 


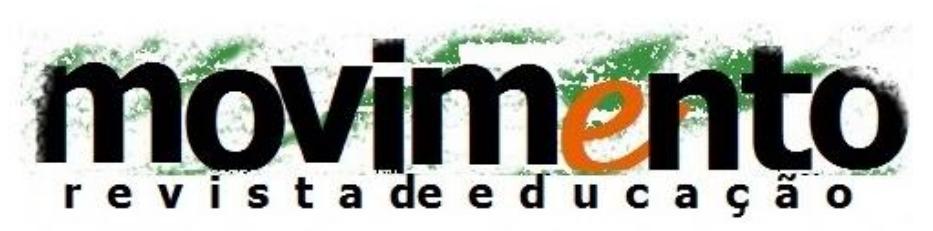

faculdade de educação - programa de pós-graduação em educação

universidade federal fluminense issn 2359-3296

ano 3 número 5 - 2016

própria organização desse seminário, mais aberta ao debate, nos demonstra a perspectiva e a necessidade de construção do consenso, por parte da fração burguesa multinacional e associada.

No que se refere às propostas para o sistema educacional brasileiro, o grau médio foi sempre colocado como central para a formação da força de trabalho e também para a contenção da pressão sobre a universidade. Nesse sentido, algumas propostas defendidas tiveram maior destaque ao longo do Fórum de Educação, foram elas: a educação voltada para o mercado de trabalho, o fim da gratuidade irrestrita, maior participação empresarial em todos os níveis de ensino, ampliação das possibilidades de formação com a criação dos cursos superiores de carreira curta e a terminalidade do ensino médio. Apesar de todos esses pontos estarem, de alguma forma, interligados, os dois últimos merecem especial atenção por representarem uma solução que visava conciliar as demandas do mercado de trabalho com a correlação de forças que tinha nos estudantes um de seus principais focos de resistência.

Desse modo, é na articulação dos diferentes níveis educacionais e na hierarquização no interior do sistema de ensino que reside a potência da educação para a reprodução do capital e de seu sistema de classes. Produzindo e reproduzindo diferenças sociais, a escola e as instituições de ensino superior são chamadas a formar para o capital e a conformar com as suas contradições. O IPES tentou adequar, aos seus interesses, a demanda da sociedade pela expansão educacional, através de uma hierarquização dos estabelecimentos e graus de ensino capaz de fornecer diferentes tipos de qualificação para a composição dos quadros do mercado de trabalho e de seu exército de reserva. 


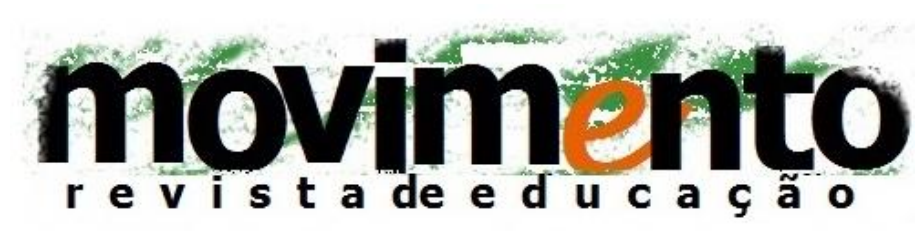

faculdade de educação - programa de pós-graduação em educação

universidade federal fluminense

issn 2359-3296

ano 3 número 5 - 2016

A expansão educacional que, em função das pressões sociais, pode ir além do necessário, teve de ser compensada por meio da desqualificação de algumas, ou muitas, de suas instituições e da criação de novas hierarquias internas ao sistema de ensino. Quando os empresários do IPES defenderam os cursos de curta duração, o fortalecimento da pós-graduação, e a terminalidade do ensino médio, por exemplo, eles estavam criando novos mecanismos de reproduzir a estrutura de classes mesmo com uma expansão do ensino superior indesejada, mas incontornável frente ao movimento da Reforma Universitária.

É também no bojo dessa articulação em torno da educação que vemos a possibilidade de conformação dos interesses dos empresários industriais e empresários de ensino, dando aos últimos a possibilidade de manejar o tipo formação oferecida dentro de suas necessidades corporativas.

\section{Os Congressos nacionais dos estabelecimentos particulares de ensino}

Desde os tempos de colônia, a Igreja Católica teve protagonismo em grande parte da história da educação brasileira. Até o governo de Getúlio Vargas, a sua hegemonia se materializava na quase totalidade da oferta de ensino em mãos das instituições confessionais. ${ }^{16}$ Mesmo após esse período, quando o Estado começa a incidir e a ocupar a esfera educacional, as instituições particulares mantiveram sua força e tinham na Igreja Católica a principal articuladora de seus interesses (MINTO, 2006).

\footnotetext{
${ }^{16}$ Desde a vinda da família real portuguesa para o Brasil, em 1808, já havia um incipiente processo de construção de estabelecimentos de ensino oficiais, mas não chegavam perto de competir com a amplitude da Igreja.
} 


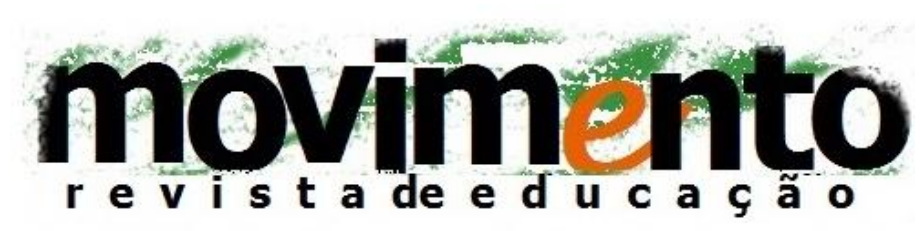

faculdade de educação - programa de pós-graduação em educação

universidade federal fluminense

issn 2359-3296

ano 3 número 5 - 2016

$\mathrm{Na}$ década de 1960, os empresários de ensino começaram a adquirir certa autonomia, mas ainda gozavam do prestígio das escolas confessionais e da ingerência da Igreja na administração pública ligada à educação ${ }^{17}$. Essa articulação de interesses e de defesas, entre a escola particular leiga e confessional, se expressava em espaços organizativos comuns, como os Congressos Nacionais dos Estabelecimentos Particulares de Ensino que, surgidos em 1944, continuaram representar ambos os campos mesmo após o golpe de 1964.

Nesse sentido, devemos lembrar que Federação Nacional dos Estabelecimentos de Ensino - FENEN e a Associação das Escolas Católicas do Brasil - AEC eram as principais instituições da sociedade civil empenhadas, em seus anos iniciais, na organização desses Congressos ${ }^{18}$. Na realidade, o próprio surgimento da FENEN se deu a partir do $1^{\circ}$ CONEPE, sendo oficializada em 1948, no mesmo período em que surgiu a AEC tendo em vista a defesa dos interesses confessionais para a educação. Esse foi o contexto em que os representantes da escola particular tiveram que contar com espaços de organização para a defesa de seus interesses, visto que se iniciava um movimento em torno da defesa da educação pública (SCARFONI, 2012).

Os CONEPEs, que deveriam se realizar em intervalos de um a dois anos, eram organizados por uma comissão executiva que se tornava responsável por convidar também autoridades públicas e de instituições estatais. Para fortalecer esse vínculo com os aparelhos de Estado, as conclusões congressuais eram

\footnotetext{
17 A separação dos dois campos da educação particular, católica e laica, a partir de atuações e projetos distintos, se dará na década de 1980 (OLIVEIRA, 2002). No entanto, entendemos que as figuras mais orgânicas dos CONEPEs já preparavam defesas específicas para os interesses privados.

${ }^{18}$ No CONEPE de 1964, somente a FENEN aparece como organizadora, mas membros das escolas católicas continuaram a participar por todo o período analisado.
} 


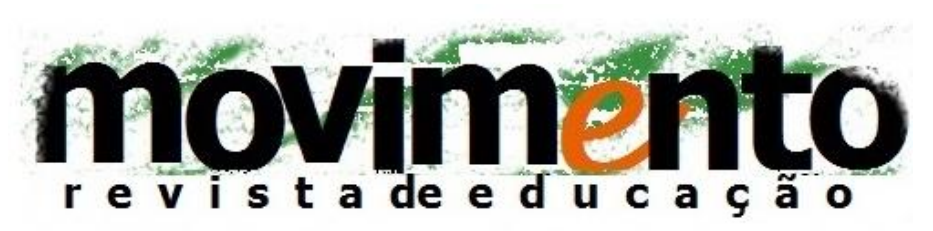

faculdade de educação - programa de pós-graduação em educação

universidade federal fluminense issn 2359-3296

ano 3 número 5 - 2016

enviadas ao legislativo. Participavam dos congressos representantes das escolas particulares, sindicalizadas ou não, mas que sofriam alguma pressão para sindicalizarem-se, tendo em vista o fortalecimento da FENEN.

No todo dos congressos, algumas questões de ordem corporativa sobressaiam, como a demanda por subvenções estatais e a preocupação com o fundo público, a questão das mensalidades com críticas à sua fixação e também a "liberdade de ensino", entendida como a liberdade de as famílias escolherem as escolas e o tipo de ensino para seus filhos (OLIVEIRA, 2002). No entanto, ao longo dos anos, o contexto social trouxe novas determinações para essas defesas corporativas, principalmente pelo fato de a formação exclusiva da elite dirigente ceder lugar a uma incipiente democratização da educação, a qual as escolas particulares tiveram de se adaptar.

Foi nesse contexto de expansão da oferta educacional, associada à campanha em defesa da escola pública, que seria germinada a Lei de Diretrizes e Bases da Educação Nacional, de 1961. Disputando o protagonismo na democratização do acesso à educação, assim como o auxílio estatal, a escola particular foi a principal beneficiada com a nova legislação. Nesse processo, não somente a Igreja Católica contribuiu no lobby para seu favorecimento, mas também os CONEPEs se somaram na definição das principais linhas do projeto a ser defendido (SCARFONI, 2012).

Apesar disso, os anos 1950 e o início dos anos 1960 foram conturbados para os donos dos estabelecimentos particulares de ensino. Girando em torno do problema do aumento das anuidades, os conflitos se estabeleciam com pais, alunos e, durante o seu governo, também com algumas autoridades próximas a João Goulart. Quando do golpe de 1964, esses empresários viram-se com 


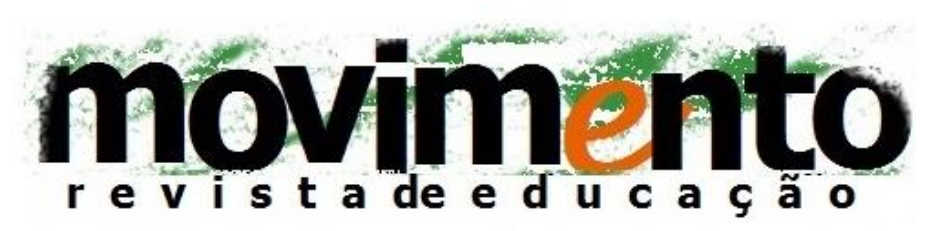

faculdade de educação - programa de pós-graduação em educação

universidade federal fluminense

issn 2359-3296

ano 3 número 5 - 2016

chances de terem suas demandas atendidas (LIRA, 2010). No entanto, se, por um lado, os aparelhos de Estado da ditadura mostravam-se permeáveis às demandas da escola particular, por outro, a fração de classe hegemônica, desse período, também tinha política para a educação e com ela os empresários de ensino precisavam dialogar.

Dessa forma, é interessante notar que os setores ligados à escola particular, participantes dos Congressos Nacionais dos Estabelecimentos Particulares de Ensino, eram hegemonizados pelos empresários articulados no Instituto de Pesquisa e Estados Sociais, mesmo no que se refere ao campo educacional.

Isso pode ser explicado pelo fato de que os empresários de ensino, em função de seu corporativismo, não se propunham à construção de um projeto de sociedade, mas incorporavam os projetos hegemônicos e neles incluíam os seus interesses específicos. Em uma fala de Carlos Alberto Werncek, presidente da FENEN, no IX CONEPE, o próprio congressista parece nos dar a pista de como os empresários de ensino vislumbravam a sua relação com outras frações da classe dominante.

[...] essa preocupação dos educadores da seara privada, em ajustar constantemente a educação à realidade nacional, constitui uma tônica, uma constante em nossos trabalhos, porque acreditamos sinceramente 'que nada há de mais lamentável do que o divórcio entre conhecimento e a vida' (CONEPE, 1966, p. 18).

$\mathrm{Na}$ esteira do projeto de sociedade que vinha se articulando no IPES, portanto, os CONEPEs inseriam as suas demandas corporativas. Corroborando com a perspectiva da Teoria do Capital Humano, da educação em função do desenvolvimento nacional e individual, os empresários de ensino defendiam a 


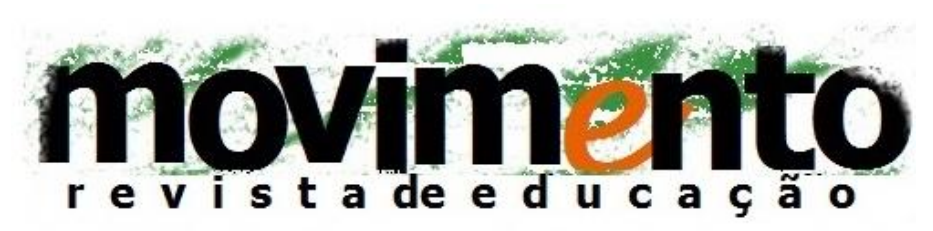

faculdade de educação - programa de pós-graduação em educação

universidade federal fluminense

issn 2359-3296

ano 3 número 5 - 2016

sua participação na condução desse processo. Em outros termos, os empresários que vendiam a educação-mercadoria incorporaram os ideais do empresariado que demandava a mercadoria-educação de modo a garantir a reprodução de suas vantagens comerciais, a partir da defesa do projeto de sociedade hegemônico. O que os empresários de ensino priorizavam, portanto, não era a democratização ou elitização da educação, mas a contemplação de suas demandas corporativas.

A incorporação dos ideais de democratização da educação nos marcos da Teoria do Capital Humano, ideais esses ausentes em congressos anteriores (SCARFONI, 2012), fica clara no discurso de Dalton Oliveira Viana, presidente da comissão executiva do nono CONEPE:

Em nossos dias, educar-se não é mais apenas cultivar-se o espírito, mas adquirir valioso instrumento de trabalho, necessário à produção de bens essenciais à vida. Sobre ser fator de aprimoramento do indivíduo, encarada tão só no seu aspecto cultural, a educação representa, no sentido econômico, elemento indispensável à prosperidade de uma nação e, sob o ponto de vista libertário, o único veículo de libertação de um povo (CONEPE, 1966, p. 9).

Não obstante, os interesses específicos dos donos de escolas particulares não eram negligenciados, sendo as principais defesas aquelas que versavam sobre as bolsas de estudos e a liberdade de ensino. Essas defesas sustentavam que as famílias tinham de ter liberdade de escolher a educação de seus filhos, sendo ela pública ou privada. O Estado, por sua vez, era responsável por garantir essa liberdade a partir da concessão de bolsas e outras formas de favorecimento à escola particular. No discurso de Carlos Alberto Werncek, presidente da FENEN: 


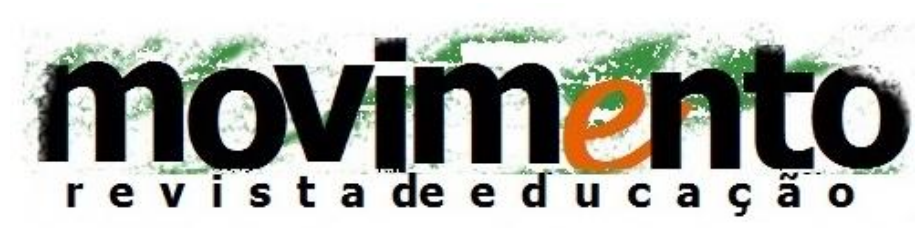

faculdade de educação - programa de pós-graduação em educação

universidade federal fluminense

issn 2359-3296

ano 3 número 5 - 2016

[...] nós todos, educadores da escola privada, acreditamos sinceramente na instituição de bolsas e sentimos que essa é a forma pela qual o governo pode proporcionar a cada um o direito de aspirar à escola de sua escolha, de optar pelo gênero de educação que a família deseje, o direito de poder realizar aquilo que realmente constitui, não apenas um preceito legal, não apenas um mandamento constitucional, mas que seu íntimo pede, e que num regime democrático, é um direito de todos (CONEPE, 1966, p. 22).

Dessa forma, ainda que as questões corporativas fossem priorizadas, elas se adequaram ao contexto educacional ao longo dos anos. Se, nos primeiros congressos, os diretores se colocavam a tarefa da formação das elites por meio da educação secundária, conforme a democratização do ensino foi se tornando uma tendência, eles começaram a pleitear o protagonismo da expansão via subvenção estatal. A justificativa para isso era a dita liberdade de ensino, em contraposição ao monopólio estatal. Já em meados da década de 1960, a Teoria do Capital Humano é incorporada e a formação para o mercado de trabalho é colocada como uma demanda prioritária para educação.

Dialogando, portanto, com o projeto de sociedade hegemônico, os empresários de ensino buscavam se adequar e se beneficiar das políticas que incidiam sobre a educação. No entanto, nem sempre as expectativas eram atendidas, gerando insatisfações e embates por parte dos representantes da escola particular. A despeito da possibilidade de conformação de interesses, deve-se destacar que, em períodos de maior tensão, os congressos foram marcados por táticas mais agressivas em relação ao que se consolidava. Foi o que ocorreu quando do debate sobre a profissionalização do ensino médio, que elevaria os custos da escola particular (CONEPE, 1967). No entanto, sem força para enfrentar, ao menos num primeiro momento, os empresários de ensino recuaram e buscaram se adaptar, novamente pleiteando subvenções públicas para a incorporação da proposta (CONEPE, 1971). 


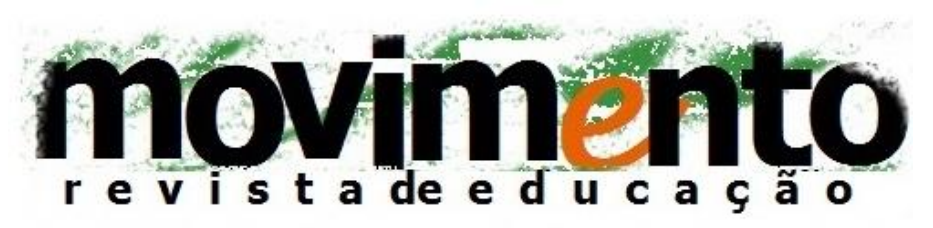

faculdade de educação - programa de pós-graduação em educação

universidade federal fluminense issn 2359-3296

ano 3 número 5 - 2016

Combinando adequação e pressão, os participantes dos CONEPEs visavam incidir sobre as reformas educacionais que se avizinhavam e, quando tensionados, se aproveitavam da correlação de forças para conquistar maior ressonância em suas ideias.

\section{Conclusão}

A ditadura empresarial-militar brasileira, através de suas políticas públicas, foi o momento em que o sistema educacional consolidou a subsunção da educação aos interesses do desenvolvimento econômico e industrial. Paralela a essa adequação, também a mercantilização da educação teria, nesse período, um favorecimento para sua expansão. Essa dupla forma de "privatização" - que submetia a educação aos interesses privados ao mesmo tempo em que a colocava como uma mercadoria - beneficiava frações de classe distintas. Por um lado, o empresariado industrial tinha a sua demanda pela formação da força de trabalho atendida e, por outro, os empresários de ensino viam-se contemplados pelas políticas que contribuíam para a manutenção e crescimento de seus lucros. Esses interesses, ainda que diferentes, não se mostravam inconciliáveis, podendo se conformar em um projeto único de educação.

Ao analisarmos o projeto educacional que, vinculado a um orgânico projeto de sociedade, era defendido pelo IPES pudemos perceber que os interesses das escolas particulares não eram atacados e a ele poderia se associar. Tendo em vista que o projeto de classe, organizado no Instituto, previa não somente a formação para o trabalho, mas também a formação de uma determinada 


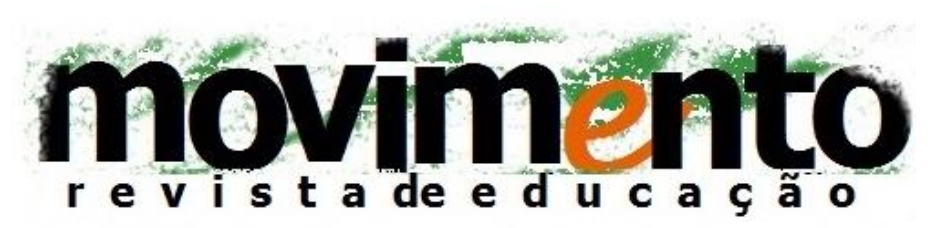

faculdade de educação - programa de pós-graduação em educação

universidade federal fluminense issn 2359-3296

ano 3 número 5 - 2016

sociabilidade combinada com a conformação com suas contradições, a privatização da educação pode se inserir nas lacunas deixadas por uma expansão educacional que ia além das necessidades do mercado. Além disso, um contexto de ameaça aos interesses burgueses, representado pelo ordenamento mundial da guerra fria e pelas tentativas de reformas do governo de João de Goulart, as frações empresariais brasileiras se encontravam mais preocupadas com o consenso dentro da classe dominante do que com a defesa frontal de seus interesses específicos. Foi o que nos mostraram os documentos do IPES e, com algumas nuances, também se evidenciou nas proposições dos CONEPEs.

\section{Referências}

CAMPOS, Renata A. O IPES E OS CONEPEs: Conflitos e Consensos em torno dos rumos da política educacional da ditadura empresarial-militar brasileira. 2016. 202f. Dissertação (Mestrado em Educação) - UFF, Niterói.

CONEPE. 8., 1964, Salvador. Anais... Salvador, 1964. . 9., 1966, Curitiba. Anais... Curitiba, 1966. . 10., 1967, Fortaleza. Anais... Fortaleza, 1967. . 11., 1969, Rio de Janeiro. Anais... Rio de Janeiro, 1969. . 12., 1971, Recife. Anais... Recife, 1971.

CUNHA, Luís Antônio. A Universidade Reformanda. Rio de Janeiro: Francisco Alves, 1988.

DREIFUSS, René Armand. 1964: a conquista do Estado. Ação Política, Poder e Golpe de Classe. Petrópolis: Vozes, 1981. 


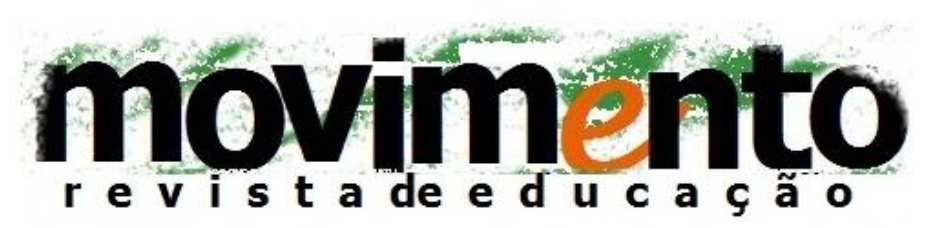

faculdade de educação - programa de pós-graduação em educação

universidade federal fluminense

issn 2359-3296

ano 3 número 5 - 2016

FERNANDES, Florestan. A revolução burguesa no Brasil. São Paulo: Globo, 2005.

FREITAG, Bárbara. Escola, Estado e Sociedade. São Paulo: Editora Moraes, 1986.

GRAMSCI, Antonio. Os intelectuais e a organização da cultura. Rio de Janeiro: Civilização Brasileira, 1979.

. Cadernos do Cárcere, volume 3: Maquiavel. Notas sobre o Estado e a Política. 6 ed. Rio de Janeiro: Civilização Brasileira, 2014.

IPES. Simpósio sobre a Reforma da Educação. Documento Básico. Rio de Janeiro, 1964a.

- Simpósio sobre a Reforma da Educação. Delineamento Geral de um Plano de Educação para a Democracia no Brasil. Rio de Janeiro, 1964b.

1964c.

. Boletim Mensal: A Reforma da Educação. Rio de Janeiro, . A educação que nos convém. Rio de Janeiro: Apec, 1969.

LIRA, Alexandre Tavares Nascimento. A legislação de educação no Brasil durante o regime militar (1964-1985): um espaço de disputas. 2010. 367f. Tese (Doutorado em Educação) - UFF, Niterói.

MINTO, Lalo Watanabe. As reformas do ensino superior no Brasil: o público e o privado em questão. Campinas: Autores Associados, 2006.

NETTO, José Paulo. Pequena História da Ditadura (1964-1985). São Paulo: Cortez Editora, 2014.

OLIVEIRA, Marcos Marques. Os empresários da educação e o sindicalismo patronal. Bragança Paulista: Editora da Universidade São Francisco, 2002.

RODRIGUES, José. Os empresários e a educação superior. Campinas: Autores Associados, 2007. 


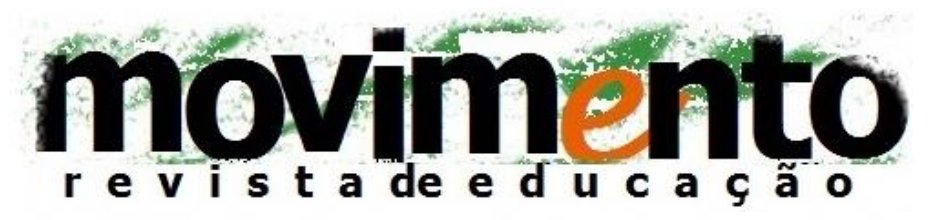

faculdade de educação - programa de pós-graduação em educação

universidade federal fluminense issn 2359-3296

ano 3 número 5 - 2016

ROMANELLI, Otaíza de O. História da Educação no Brasil. Petrópolis: Vozes, 1982.

SAVIANI, Dermeval. O Legado Educacional do Regime Militar. Caderno Cedes. Campinas, v. 28, n. 76, p. 302, set-dez. 2008.

- História das idéias pedagógicas no Brasil. $3^{\mathrm{a}}$ ed. Campinas, Autores Associados, 2010.

SCARFONI, Eduardo Norcia. Os Congressos Nacionais dos estabelecimentos particulares de ensino: CONEPE (1944-1964): a construção do consenso pela continuidade dos subsídios do Estado ao ensino privado. 2012. $120 \mathrm{f}$. Dissertação (Mestrado em Educação e Formação) - Universidade Católica de Santos, Santos.

SHULTZ, Theodore W. O Capital Humano: investimentos em educação e pesquisa. Rio de Janeiro: Zahar, 1973.

SOUZA, M. I. Os Empresários e a Educação: o IPES e a política educacional após 1964. Petrópolis: Vozes, 1981. 